\title{
Sinema II: Zaman İmge Üzerine Bir İnceleme
}

\author{
Inceleyen: Melike Büyü
}

\section{Özet}

Gilles Deleuze'ün Sinema 1: Hareket-İmge kitabının ikinci cildi olan Sinema 2: Zaman-İmge kitabında, ilk cilde oranla okuyucuyu görece zorlu bir okuma süreci beklemektedir. Deleuze, okuyucudan duyu-motor şemasının ötesine geçmesini bekler. Kitap, en başından itibaren okuyucuya yeni kavramlar sunar; bu kavramları kitabın farklı bölümlerinde tartışır ve bunu yaparken sinema tarihindeki onlarca farklı filme ve Federico Fellini, Alfred Hitchcock, Orson Welles gibi birçok farklı yönetmene atıf yapar.

Türkiye' de Ocak, 2021 tarihinde çevirisi yapılarak yayımlanan kitap, 10 farklı bölümden oluşmaktadır. Kitap teoriktir ve okuyucuya yeni kavramlar sunarken, bunları doğru şekilde algılayabilmek adına belirli bir bilgi birikimine ihtiyaç duyulur. Bu anlamda kitap, belirli kavramlara ve görece sinemaya hâkim, entelektüel bir okuyucu kitlesine hitap eder. Her ne kadar Deleuze, okuyucuya karmaşık kavramlar, terimler ve deneyimlenmesi gereken yeni kapılar açsa da kitabın akıcı bir üslupla yazıldığı, aynı zamanda Türkçeye iyi çevrilmiş bir kitap olduğu söylenebilir. Deleuze, Zaman-İmge kitabında, hareket-imge kavramını, oldukça etkilendiği Bergson ve Kant gibi düşünürlerin zaman kavramları üzerinden aşar. Bu kitapla ilgili en önemli ve temel noktalardan biri, Deleuze'ün sinemayı bir dil olarak görmemesidir.

Deleuze için aksine sinema, "dil öncesi imgeler ve göstergeler sistemidir" (Deleuze, 2021: 318). Fakat kitabın asıl meselesi bu değildir. Asıl mesele "sinemadaki imge ve göstergeler sisteminde, iki imge arasındaki ilgili göstergeleriyle hareket imgeler ile zaman imgeler arasındaki ayrımdır" (2021: 330). Deleuze, tüm kitap boyunca, zaman-imgeyi birçok farklı kategori çerçevesinde, üstüne yeni düşünceler ve kavramlar ekleyerek tartışırken, okuyucu kitabın sonunda Deleuze' ün zaman-imgeyle ne anlatmak istediğini artık kavramış olur. Aynı zamanda okuyucu, sorgulaması gereken birçok düşünceyle de baş başa kalır. Bu anlamda Deleuze'ün kitabı yazarken yaklaşımının, hedef kitlenin beklentilerini karşılayacak nitelikte olduğunu rahatlıkla söyleyebiliriz.

Deleuze, Zaman-İmge kitabında üstünde uzun uzun düşünmemizi gerektirecek bir teori sunar: "İmge, duyu- motor olmaktan çıkmıştır ve gerçek artık temsil edilen veya yeniden üretilen bir şey değildir" (2021: 208). Deleuze, bununla ne demek ister? Deleuze, imgenin duyu-motor olmaktan uzaklaşmasını 2. Dünya savaşı sonrasında ortaya çıkan modern sinema ile ilişkilendirir. Ona göre 2. Dünya savaşı öncesinde sinemaya hareket-imge hakimdir. Bu dönemde az sayıda da olsa zaman-imge filmleri mevcuttur; fakat zamanimgeyle asıl tanışmamız, sinemanın savaş sonrasında yeni arayışlar ve keşifler içerisinde olmasıyla gerçekleşir. 
Savaş öncesindeki klasik sinemaya hâkim olan montaj, harekete bağlı olarak biçimlenirken; filmler zamanın doğrudan sunumuna sahip değildir. Yasujiro Ozu'nun filmleriyle ise artık zamanın doğrudan sunumunu, zaman-imgeyi, keşfetmeye başlarız. Öyleyse modern sinemayla çöken duyu-motor şemasının yerini ne alır? Bu sorunun cevabı Deleuze'ün Sekizinci Bölüm'de (Sinema, Beden, Beyin ve Düşünce) yer alan modern sinemayı özetlediği şu cümlede bulabiliriz: "Bana bir beyin verin" (2021: 249). Sinema artık ardışık olarak birbirini takip eden eylemlerden çok düşünceyle, düşünmeyle ilgili bir hale gelir. Modern sinemayla çöken duyu- motor şemasıyla birlikte "İzleyicin meselesi sonraki sahnede neler göreceğiz sorusu olmaktan çıkarak imgede görülecek olan nedir sorusu olmaktan çıkarak imgede görülecek olan nedir?" (2021: 332). Sorusu şeklini alır. Artık imgenin kendisi önemlidir, karakterin ve izleyicinin ise düşünmesi önemli bir hal alır. Bu kitap okuyucudan imgelere bakmasını değil, imgeleri görmesini ister.

Peki düşünülecek olan nedir? Daha da önemlisi sinemadaki imgeler aracılığıyla düşünmek mümkün müdür? Deleuze bunu Yedinci Bölüm'de (Düşünce ve Sinema) Artaud, Schäfer gibi düşünürler üzerinden tartışır. Özellikle Artaud, sinema-düşünce ilişkilerinin hepsini alaşağ1 eder. "Ne bir yanda montaj yoluyla düşünebilecek bir bütün; ne de diğer yanda imge yoluyla dile getirilebilecek bir iç monolog vardır." (2021, 223). Duyu-motor şemasının bozulmasıyla eylemlerin bir önemi kalmadıysa ve düşünülebilecek tek şey düşünemeyişimiz ise sinema bize zaman-imge ile ne sunmayı amaçlar? Deleuze'e göre soru artık "Sinema bize dünyaya olan inanc1 nasıl geri verir" (2021: 223). Sorusuna dönüşür. Sinema artık bir inanç meselesi haline gelir. Bu sinemaya dair oldukça sarsıcı ve önemli bir teoridir.

Sinemanın bir inanç meselesine dönüşmesi, sinemanın, öykünün, karakterlerin, olayların da dönüşmesi demektir. Bu, teknolojiyle, insanların gelişmesiyle ulaşılan bir dönüşüm değil; aksine insanın doğadan, dünyadan kopuşuyla kaybettiği bir şeyleri yeniden bulma, onu yeniden var etmeye çalışmasının bir dönüşümü olarak karşımıza çıkması anlamına gelir. "Mesele sözcüklerin ötesinde ya da berisinde dünyaya olan inancı bulmak ve geri getirmektir" (2021: 212). İnsan ve doğanın bağının kopmasıyla beraber artık tüm mesele kaybedilen bu bağı, sinemayla yeniden kurabilmektir.

Bu durumun günümüz için de geçerli olduğunu söyleyebilir miyiz? Günümüzde insanların her gün maruz kaldığı imgeleri göz önüne alırsak, zaman-imgenin yitirilmeye başladığını da düşünebilir miyiz? Teknolojinin ilerlemesiyle birlikte sokakta, evde, arabada, yemek yerken, uyumadan önce, uyandıktan hemen sonra, bir arkadaşımızla sohbet ederken vs. yüzlerce imgeye maruz kalmaktayız. Bu imgeler bazen çok hızlı bir şekilde belirip kaybolmaktadırlar. Bu durumun, genel sinema izleyicisi için film izlemeyi zorlaştırdığını söyleyebilir miyiz? Çağımızda genel olarak izleyici, alıştığı şekilde görüntüden hız, aksiyon, hareket, etkitepki beklemektedir. Yavaşlı̆̆ı, düşünmeyi, imgeleri sorgulamayı, bunlar üzerine fikirler üretmeyi, imgeleri keşfetmeyi isteyen bir izleyici kitlesinin varlığ her geçen gün azalıyor gibi görünmektedir. Her şeyin dijitalleştiği, hızlandığı, efektlerin, montajın değer kazandığı bir çağın tam ortasında bizler sinemayla birlikte dünyaya olan inancımızı geri getirmeye çalışıyor muyuz sorusu önem kazanmaktadır.

Dördüncü Bölüm'de (Zaman Kristalleri) tartışılan kristal imgeye değinmek de önemlidir. Deleuze'e göre, kristal imgeler zamanın dolaysız bir sunumudur. Örneğin aynalar, kristal imgelerdir. Aynalarda kendini gören karakterler (bazen tek bir aynada, bazen aynı anda onlarca farklı aynada) bir imgenin hem aktüel hem de virtüel haliyle karşı karşıya kalır. Aynada kendini gören bir karakter, yansımasında virtüel kendisiyle karşılaşır. Bu karmaşık bir durumdur. Çünkü karaktere ve izleyiciye hem şimdiyi hem de geçmişi aynı anda sunar. Şimdi ve gelecek eşzamanlı bir hale gelir. Zaman, böylece görüntüde kendi montajını yaratır. İzleyici aktüel ve virtüel arasındaki sürekli yer değiştirmeleri doğrudan algılayamayabilir. 
Çünkü ne gördüğünden emin değildir. Kristal imgede gerçek ve sanal olan o kadar birbirine benzer ki, hangisinin gerçek hangisinin sanal olduğunu anlamak güçleşir. Bu klasik sinemadaki imgelerin tam aksidir, sahnede gizleneni izleyici çözmeli, imgede ne gördüğünü anlamlandırmalıdır.

Yukarıda bahsedilen "imgede geçmiş ve geleceğin eşzamanlı hale gelmesi" ne demektir? Kitapta bunu Deleuze, özellikle Üçüncü ve Dördüncü Bölüm’ de zaman kavramından oldukça etkilendiği Bergsoncu bir yöntemle açıklar. Zaman-imgeyi anlayabilmek için Deleuze'ün Bergson'un zaman kavramından ne derece etkilendiğini kavramak önemlidir. 